\title{
Uptake of Obesity Intensive Behavioral Treatment Codes in Medicare Beneficiaries, 2012-2015
}

\author{
Shenbagam Dewar, $\mathrm{MD}^{7}$, Julie Bynum, $M D, M P H^{1,2}$, and John A. Batsis, $\mathrm{MD}^{3,4}$ \\ 'Department of Geriatric and Palliative Medicine, University of Michigan , Ann Arbor, MI , USA; ${ }^{2}$ Institute for Health Policy and Innovation, University \\ of Michigan, Ann Arbor , MI , USA; ${ }^{3}$ Section of General Internal Medicine, Geisel School of Medicine at Dartmouth , Lebanon, NH , USA; ${ }^{T}$ The \\ Dartmouth Institute for Health Policy \& Clinical Practice, Dartmouth College , Hanover , NH , USA.
}

J Gen Intern Med 35(1):368-70

DOI: $10.1007 / \mathrm{s} 11606-019-05437-1$

(c) Society of General Internal Medicine 2019

\section{INTRODUCTION}

Obesity prevalence has risen to $41 \%$ among adults aged 60 and older in the USA. ${ }^{1}$ Rising rates are predicted to have significant medical, socio-economic, and health policy implications due to cumulative multimorbidity coupled with progressive disability. In 2011, payment for intensive behavioral therapy (IBT) for obesity was approved by the Centers for Medicare and Medicaid. In 2018, US Preventive Services Task Force recommended that clinicians offer multicomponent IBT for adults of all ages with body mass index $\geq 30 \mathrm{~kg} / \mathrm{m}^{2}$, but outline the limited evidence of long-term health outcomes in older adults. ${ }^{2}$ Data favor intentional weight loss to improve function and quality of life in older adults ${ }^{3}$, despite the weakening evidence for the obesity paradox. While face-to-face individual IBT and group codes (added in 2015) pay for up to 22 visits/ year in primary care, there is concern about underutilization of IBT due to operational challenges. ${ }^{4,5}$ Our objective was to analyze the trends in uptake of IBT during the initial 4 years of implementation.

\section{METHODS}

We performed serial, cross-sectional analyses of Medicare Part B claims for IBT for both individual and group visits between 2012 and 2015, including fee-for-service Medicare beneficiaries enrolled in Parts A and B. Demographic

Presentations This will be presented at the American Geriatric Society annual meeting to be held in Portland, OR, on May 3, 2019.

Received February 26, 2019

Revised July 3, 2019

Accepted September 23, 2019

Published online October 22, 2019 data were obtained from the Medicare denominator file. We report IBT use as the number and percentage of beneficiaries using IBT and the number of IBT visits per beneficiary. Common Procedural Treatment Code of G0447 and G0473 (for individual and group counseling, respectively) identified IBT. The uptake rate per 1000 beneficiaries with obesity was calculated as a ratio of the number of beneficiaries utilizing IBT (based on Part B claims) to the state-specific prevalence of obesity, as previously described using Behavioral Risk Factor Surveillance System data. ${ }^{4}$ Due to the current disparities in state obesity prevalence, IBT uptake by state was analyzed to study correlation of uptake to the magnitude of obesity challenge. Aggregated results are presented nationally, stratified by sex, race, and quintiles of state obesity prevalence (low to high).

\section{RESULTS}

Utilization remains low from 2012 to 2015 at $0.10 \%$, $0.17 \%, 0.17 \%$, and $0.20 \%$ respectively (Table 1 ). Overall uptake changed minimally over time $(3.50,6.00,6.06$, and 7.31 per 1000 beneficiaries) as did the number of visits per beneficiary. Group counseling visits were higher at 5.9 visits/beneficiary compared with 2.1 visits/beneficiary for individual counseling, although absolute use of group visits was low. There was no significant correlation between quintiles of state obesity prevalence and uptake in each year of the benefit (Fig. 1).

\section{DISCUSSION}

IBT for obesity in Medicare beneficiaries remains underutilized, even in states with high obesity prevalence. We found no increase in the number of beneficiaries for either individual or group counseling over its first 4 years, although those using the benefit received more visits if 
Table 1 Intensive Behavioral Therapy Claims (G0447, G0473) Among Medicare Beneficiaries, 2012-2015

\begin{tabular}{|c|c|c|c|c|c|c|c|c|c|c|}
\hline & \multirow{2}{*}{\multicolumn{2}{|c|}{$\begin{array}{l}\text { CY2012 } \\
\text { Individual G0447 }\end{array}$}} & \multirow{2}{*}{\multicolumn{2}{|c|}{$\begin{array}{l}\text { CY2013 } \\
\text { Individual G0447 }\end{array}$}} & \multirow{2}{*}{\multicolumn{2}{|c|}{$\begin{array}{l}\text { CY2014 } \\
\text { Individual G0447 }\end{array}$}} & \multirow{2}{*}{\multicolumn{2}{|c|}{$\begin{array}{l}\text { CY2015 } \\
\text { Individual G0447 }\end{array}$}} & \multirow{2}{*}{\multicolumn{2}{|c|}{$\begin{array}{l}\text { CY2015 } \\
\text { Group G0473 }\end{array}$}} \\
\hline & & & & & & & & & & \\
\hline & $\begin{array}{l}\text { No. of } \\
\text { users } \\
N(\%)\end{array}$ & $\begin{array}{l}\text { Claims } \\
\text { per user* }\end{array}$ & $\begin{array}{l}\text { No. of } \\
\text { users } \\
N(\%)\end{array}$ & $\begin{array}{l}\text { Claims } \\
\text { per user* }\end{array}$ & $\begin{array}{l}\text { No. of } \\
\text { users } \\
N(\%)\end{array}$ & $\begin{array}{l}\text { Claims } \\
\text { per user* }\end{array}$ & $\begin{array}{l}\text { No. of } \\
\text { users } \\
N(\%)\end{array}$ & $\begin{array}{l}\text { Claims } \\
\text { per user* }\end{array}$ & $\begin{array}{l}\text { No. of } \\
\text { users } \\
N(\%)\end{array}$ & $\begin{array}{l}\text { Claims } \\
\text { per user* }\end{array}$ \\
\hline $\begin{array}{l}\text { Overall } \\
\text { count }\end{array}$ & $\begin{array}{l}27,338 \\
(0.1)\end{array}$ & 1.99 & $\begin{array}{l}46,821 \\
(0.17)\end{array}$ & 2.16 & $\begin{array}{l}46,171 \\
(0.17)\end{array}$ & 2.18 & $\begin{array}{l}57,136 \\
(0.2)\end{array}$ & 2.10 & $\begin{array}{l}440 \\
(0.0)\end{array}$ & 5.90 \\
\hline \multicolumn{11}{|l|}{ Sex } \\
\hline Female & $\begin{array}{l}16,894 \\
(0.11)\end{array}$ & 2.06 & $\begin{array}{l}29,195 \\
(0.18)\end{array}$ & 2.24 & $\begin{array}{l}28,120 \\
(0.18)\end{array}$ & 2.25 & $\begin{array}{l}34,414 \\
(0.22)\end{array}$ & 2.17 & $\begin{array}{l}319 \\
(0.0)\end{array}$ & 6.01 \\
\hline Male & $\begin{array}{l}10,444 \\
(0.09)\end{array}$ & 1.87 & $\begin{array}{l}17,626 \\
(0.14)\end{array}$ & 2.03 & $\begin{array}{l}18,051 \\
(0.15)\end{array}$ & 2.06 & $\begin{array}{l}22,722 \\
(0.18)\end{array}$ & 1.99 & $\begin{array}{l}121 \\
(0.0)\end{array}$ & 5.64 \\
\hline \multicolumn{11}{|l|}{ Racet } \\
\hline Black & $\begin{array}{l}2588 \\
(0.12)\end{array}$ & 1.89 & $\begin{array}{l}4682 \\
(0.21)\end{array}$ & 2.09 & $\begin{array}{l}4744 \\
(0.22)\end{array}$ & 2.11 & $\begin{array}{l}6206 \\
(0.29)\end{array}$ & 2.05 & $62(0.0)$ & 3.29 \\
\hline $\begin{array}{l}\text { Non- } \\
\text { Black }\end{array}$ & $\begin{array}{l}24,750 \\
(0.10)\end{array}$ & 2.00 & $\begin{array}{l}42,139 \\
(0.16)\end{array}$ & 2.17 & $\begin{array}{l}41,427 \\
(0.16)\end{array}$ & 2.18 & $\begin{array}{l}50,930 \\
(0.20)\end{array}$ & 2.10 & $\begin{array}{l}378 \\
(0.0)\end{array}$ & 6.33 \\
\hline \multicolumn{11}{|c|}{ State-level obesity prevalence quintilest } \\
\hline Quintile 1 & $\begin{array}{l}5703 \\
(0.09)\end{array}$ & 2.11 & $\begin{array}{l}5437 \\
(0.12)\end{array}$ & 2.02 & $\begin{array}{l}14,332 \\
(0.21)\end{array}$ & 2.13 & $\begin{array}{l}16,897 \\
(0.28)\end{array}$ & 2.04 & $\begin{array}{l}134 \\
(0.01)\end{array}$ & 8.16 \\
\hline Quintile 2 & $\begin{array}{l}3772 \\
(0.09)\end{array}$ & 2.00 & $\begin{array}{l}14,564 \\
(0.21)\end{array}$ & 2.24 & $\begin{array}{l}2946 \\
(0.09)\end{array}$ & 2.68 & $\begin{array}{l}14,819 \\
(0.27)\end{array}$ & 2.00 & $46(0.0)$ & 3.54 \\
\hline Quintile 3 & $\begin{array}{l}3375 \\
(0.09)\end{array}$ & 2.10 & $\begin{array}{l}4928 \\
(0.09)\end{array}$ & 2.47 & $\begin{array}{l}13,507 \\
(0.26)\end{array}$ & 2.11 & $\begin{array}{l}5523 \\
(0.12)\end{array}$ & 2.13 & $75(0.0)$ & 4.92 \\
\hline Quintile 4 & $\begin{array}{l}6385 \\
(0.09)\end{array}$ & 1.78 & $\begin{array}{l}8127 \\
(0.13)\end{array}$ & 2.09 & $\begin{array}{l}5148 \\
(0.11)\end{array}$ & 2.12 & $\begin{array}{l}11,982 \\
(0.18)\end{array}$ & 2.09 & $0(0.0)$ & 0.00 \\
\hline Quintile 5 & $\begin{array}{l}1835 \\
(0.03)\end{array}$ & 2.23 & $\begin{array}{l}3919 \\
(0.08)\end{array}$ & 2.26 & $\begin{array}{l}10,221 \\
(0.14)\end{array}$ & 2.20 & $\begin{array}{l}6204 \\
(0.12)\end{array}$ & 2.27 & $\begin{array}{l}1049 \\
(0.03)\end{array}$ & 6.19 \\
\hline
\end{tabular}

Values represented are number of beneficiaries availing of the IBT benefit (percentage). The number of eligible Medicare beneficiaries whose body mass index (BMI) was $\geq 30 \mathrm{~kg} / \mathrm{m}^{2}$ in 2012, 2013, 2014, and 2015 was 27,971,740; 28,146,952; 27,767,493; and 27,954,001, respectively

$C Y$ calendar year

*Claims per user represent the ratio of the overall number of any intensive behavioral therapy (IBT) claims and the number of beneficiaries using IBT beneficiary population in the given stratum; claims were fee-for-service Medicare Part B claims

†Proportion of IBT users with obesity that are classified as Black do not include certain states in BRFSS due to cell suppression

7 Quintiles of state-level obesity prevalence are grouped according to the lowest 20\% (quintile 1) and highest (quintile 5). Data on obesity prevalence was obtained from the 2012-2015 Behavioral Risk Factor Surveillance System (http://www.cdc.gov/brfss)

they participated in groups. The greater number of sessions for group IBT visits may partly be in response to workflow issues as group visits enhance operational efficiencies. Additional implementation barriers may be the result of a lack of clinician training for obesity counseling and an ability to efficiently document visits in the EMR; a collaborative is working toward increased training to prepare future health care professionals better. ${ }^{6}$

For a primary care office workflow, the number of visits coupled with low reimbursement relative to other potential office-based evaluation and management services could potentially explain its continued lack of implementation. While the goal uptake rate is hard to extrapolate despite the efficacy of weight loss interventions in older adults, uptake of the Annual Wellness Visit approached $17 \%$ in its first 4 years.
The competing degrees of comorbidities with variable disability could shift the focus of care of the beneficiary towards seeking treatment than prevention. The IBT's continued low uptake calls for a re-evaluation of its structural design for beneficiaries and providers. For older adults, such frequent, short (15 min) sessions may not be feasible due to competing medical priorities and transportation barriers. While the proposed congressional bill, "Treat and Reduce Obesity Act of 2017", has potential to increase obesity counseling by allowing non-physician members (e.g., clinical psychologists, registered dietitians, or other trained professionals) to provide IBT, it has not advanced since its introduction. Exploring telemedicine visits may increase uptake and extend services to persons with limited access to care, mobility dependency, or transportation barriers, particularly for rural residents. 


\section{Trends in Intensive Behavioral Therapy Uptake} by State Obesity Prevalence, 2012-2015

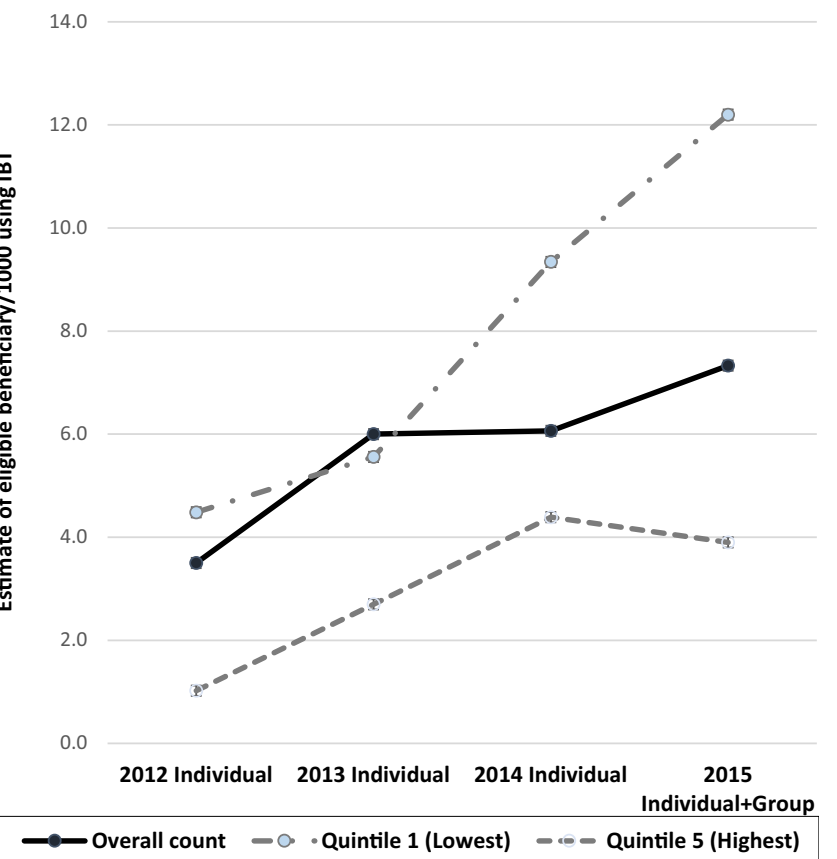

Figure 1 Trends in IBT uptake between states with lowest and highest quintiles of obesity prevalence against overall IBT uptake (individual IBT 2012-2014 and individual/group combined in 2015).

Corresponding Author: Shenbagam Dewar, MD; Department of Geriatric and Palliative Medicine University of Michigan, Ann Arbor, MI , USA (e-mail: sdewar@med.umich.edu).

Funding Information Dr. Batsis' research reported in this publication was financially supported in part by the National Institute on Aging of the National Institutes of Health under award number K23AG051681. Research reported in this publication was financially supported by the Dartmouth Clinical and Translational Science
Institute under award number UL1TROO1086 from the National Center for Advancing Translational Sciences (NCATS) of the National Institutes of Health (NIH). This work was also financially supported by the Dartmouth Health Promotion and Disease Prevention Research Center (cooperative agreement number U48DP005018) from the Centers for Disease Control and Prevention.

\section{Compliance with Ethical Standards:}

Conflict of Interest: The authors declare that they do not have a conflict of interest.

Disclaimer: The content, findings, and conclusions in this journal article are solely the responsibility of the authors and do not necessarily represent the official views of the National Institutes of Health and Centers for Disease Control and Prevention.

Publisher's Note: Springer Nature remains neutral with regard to jurisdictional claims in published maps and institutional affiliations.

\section{REFERENCES}

1. Hales CM, Fryar CD, Carroll MD. Trends in Obesity and Severe Obesity Prevalence in US Youth and Adults by Sex and Age, 2007-2008 to 20152016. JAMA - J Am Med Assoc. 2018;319(16):1723-1725.

2. Curry SJ, Krist AH, Owens DK, et al. Behavioral Weight Loss Interventions to Prevent Obesity-Related Morbidity and Mortality in Adults US Preventive Services Task Force Recommendation Statement. JAMA - J Am Med Assoc. 2018;320(11):1163-1171. https://doi.org/10.1001/jama. 2018.13022.

3. Batsis JA, Zagaria AB. Addressing Obesity in Aging Patients. Med Clin North Am. 2018;102(1):65-85. https://doi.org/10.1016/j.mcna.2017.08. 007.

4. Batsis JA, Bynum JPW. Uptake of the Centers for Medicare and Medicaid Obesity Benefit : 2012-2013. Obesity. 2016;24(9):1983-1988.

5. Batsis JA, Huyck KL, Bartels SJ. Challenges with the Medicare Obesity Benefit : Practical Concerns \& Proposed Solutions. J Gen Intern Med. 2014;30(1):118-122. doi:https://doi.org/10.1007/s11606-014-3031-6

6. Kushner R. What Do We Need to Do to Get Primary Care Ready to Treat Obesity ? Obesity. 2018;26(4):631-632. https://doi.org/10.1002/oby. 22161.

Publisher's Note Springer Nature remains neutral with regard to jurisdictional claims in published maps and institutional affiliations. 